\title{
The Ranchos of Los Adaes: Spanish Geography and American Land Claims in Western Louisiana
}

Darryl Pleaseant

Unknown

Follow this and additional works at: https://scholarworks.sfasu.edu/ita

Part of the American Material Culture Commons, Archaeological Anthropology Commons, Environmental Studies Commons, Other American Studies Commons, Other Arts and Humanities Commons, Other History of Art, Architecture, and Archaeology Commons, and the United States History Commons

Tell us how this article helped you.

This Article is brought to you for free and open access by the Center for Regional Heritage Research at SFA ScholarWorks. It has been accepted for inclusion in Index of Texas Archaeology: Open Access Gray Literature from the Lone Star State by an authorized editor of SFA ScholarWorks. For more information, please contact cdsscholarworks@sfasu.edu. 


\section{The Ranchos of Los Adaes: Spanish Geography and American Land Claims in Western Louisiana}

\section{Creative Commons License}

\section{(c) (1) (8)}

This work is licensed under a Creative Commons Attribution-NonCommercial 4.0 International License 


\title{
THE RANCHOS OF LOS ADAES: SPANISH GEOGRAPHY AND AMERICAN LAND CLAIMS IN WESTERN LOUISIANA
}

\section{Darryl Pleasant}

\begin{abstract}
Discovering the ranchos associated with the Presidio and Mission of Los Adaes has been a research goal for many years. Unfortunately research into the Spanish presence in western Louisiana never revealed documentary evidence suggesting possible locations for the ranchos. Only generalized information was recovered in regards to a couple of the ranchos but definitely not solid data on their location. Recently it has come to our attention that perhaps our search had the wrong temporal parameters, we apparently should have been focused on the period after Los Adaes was closed. The research presented within the following pages has hopefully resolved this issue.
\end{abstract}

As the title of this paper suggest geography will be the key in the discovery of the rancho locations. The eighteenth century Spanish landscape is detailed within the naming conventions used for the ranchos. The nineteenth century landscape associated with the American land claims was detailed in various congressional reports. Though separated by nearly a half century these two landscapes converged into literal road signs to possible locations for the ranchos.

It seems very likely that all of the ranchos associated with Los Adaes shared their name with a nearby creek. Names such as Tres Llanos and Llano Hondo describe the principle drainage upon which the rancho is located. The two rancho names that appear to be distinctly religious in context La Gloria and San Joseph in fact seem to once again represent drainage names. The only exception is petit ecor which is actually a French name for a region to the immediate west of Natchitoches.

It is very fortuitous that many of the drainages in the Adaes region retained their original names from the eighteenth century into the nineteenth century. An excellent example would be the Arroyo de Chacon shown in the lower center of the 1767 map of Los Adaes (Urrutia 1767). This arroyo apparently retained its name well into the nineteenth century as it appears within two Río Hondo land claims in 1823. The first was Río Hondo claim \#37 filed by James Kirkham in 1823. Kirkham states his claim is "situated on the Chacon bayou" (American State Papers 1859:97 [hereafter ASP]). The second was Río Hondo claim \#123 filed by John Sibley. In his claim he states his land is situated "up the Bayous Adaise and Chacta" (ASP 1859:113). The handwritten Río Hondo documents show the latter bayou possibly written as "Chacton" (LSLO 1823b:34). Both Río Hondo claims clearly refer to the modern drainage known as Stokers Branch located to the immediate east of Robeline, Louisiana. It is quite evident the Spanish geography was still relevant well into the American period over a half century after Los Adaes was abandoned.

The bulk of our geographic evidence in the late eighteenth and early nineteenth centuries comes from a series of land claims filed during the American period. The first relevant land claims appeared in various reports after 1813 approximately four decades after the abandonment of Los Adaes. It is however the Río Hondo land claims filed in 1823 that are the absolute essential documents in the search for the ranchos. They are some of the most important historic documents ever produced which relate to western Louisiana. It takes detailed deciphering of the various claim documents but in doing so we can reveal geographical information on rancho locations. 


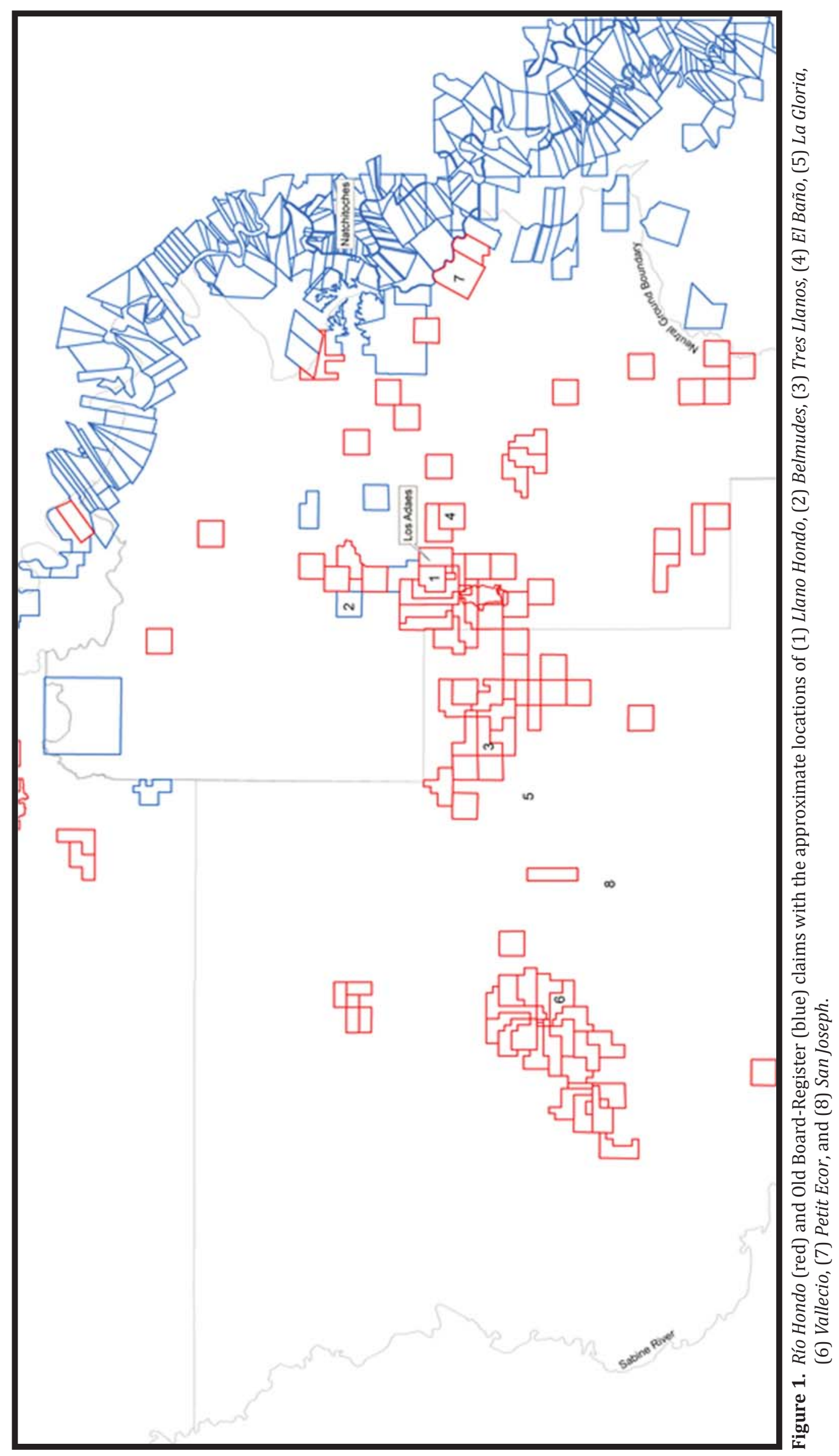


It seems information concerning the ranchos have been right in front of us for some time but was very well hidden in American land claim documents that on the surface were completely unrelated with Los Adaes or the eighteenth century. The new information was discovered literally by chance during the creation of a geodatabase of Louisiana land claims which emphasized the Río Hondo claims in the western part of the state. It was during the research associated with that project that the locations of the ranchos came to light. [To gain a better understanding of the land claims see Pleasant (2013:115-119).]

Avery (2011:234) recently stated "Once the trail [El Camino Real] and its offshoots are identified on the ground, it would simply be a matter of following the road cuts to find nearby archaeological sites". This seems to be a great idea that may come to be true. Several ranchos discussed below are situated along roads including the El Camino Real and the "Road from Natchitoches to Bayou Pierre and Pecan Point". The only variance from Avery's original statement is that now perhaps we may also be able to trace the roads back from the ranchos to Los Adaes. Shaded relief maps show road cuts near several of the proposed rancho locations. These match well with roads plotted on nineteenth century plat maps and they may well be part of older eighteenth century roads.

If the research is accurate then perhaps the ranchos could act as cornerstones in revealing the entire landscape of Los Adaes during the eighteenth century. The historic roads could connect back to Los Adaes in a manner that would seemingly complete Joseph Urrutia's map of 1767. The El Camino Real and its many branches has been a hot topic in Texas in recent years (Williams 2007; NPS 2011) and now additional branches on the Louisiana side may be close at hand.

\section{The Los Adaes Ranchos}

The documented Spanish ranchos mentioned in association with Los Adaes include Belmudes [Velmudes], Pan Y Agua, Vallecillo, Llano Hondo [Ondo], El Lobanillo, El Baño [Vaño], Tres Llanos and San Joseph. The Rancho El Lobanillo is in Texas and is not discussed further as the vital American land claims did not apply to that region. At present the whereabouts of Rancho Pan Y Agua is an absolute mystery as no additional references were located.

Ranchos La Gloria and Petit Ecor have recently come to our attention during this research and they each have a document trail available. There are other ranchos mentioned in the documents in which no additional information could be found in the course of the research. For example the deposition of Manuel de Aranbula (Béxar 1754a:46) mentions a ranch belonging to Alferez Don Pedro de Sierra [the same Alferez Sierra involved in the aftermath of the San Saba massacre and various dealings with the Taovayas]. Unfortunately there is no indication of the whereabouts or any additional information concerning Sierra's ranch.

There are also two rather curious places which also lack a paper trail. The first is the "Rancherias de la Plazuela" or just "De La Plazuela" a rancho to the immediate west of Los Adaes which appears on mid to late eighteenth century maps of the region (Urrutia 1769). This "fortified" rancho could perhaps just be a general reference to a rancho in close proximity to the presidio of Los Adaes. The second is a place called the "kings milpa" mentioned in 1754 by the governor of Los Adaes (Béxar 1754:108). A milpa is defined as an area of forest cleared and planted for several growing seasons before being abandoned for new areas. What either of these two places actually represents is not known at this time. 
The primary information concerning the ranchos in the mid-eighteenth century is found is a series of depositions in the 1750s, 1760s and 1770s (Béxar 1754a, 1755, 1774). Perhaps the most important of these documents was a petition against the governor at Los Adaes in 1754. The petition was aimed at whether the vecinos were getting fair price for "the produce of their sweat and work". The depositions within the document are the primary source on the ranchos. It is very fortunate for us that in 1754 these soldiers were unhappy with their conditions at Los Adaes or else there would be little information any of these ranchos ever existed. Afterwards there are other documents that briefly mention individual ranchos but this is the only one to have multiple mentions of the ranchos.

It would be two soldiers from Los Adaes who were stated to be rancho owners themselves that would lead the petition. They were Manuel Antonio de Losoya who owned Rancho Pan Y Agua and Salvador de Esparza who owned Rancho San Joseph. In later documents it is revealed that the petition against the governor was actually the work of Manuel Antonio De Soto Bermuda. He along with Manuel Antonio de Loyosa would eventually defect to Natchitoches to avoid prosecution over this incident (Béxar 1754b).

As previously stated Spanish geography was still relevant well into the American period and thus was surely known by many of the eighteenth century French inhabitants at Natchitoches. This suggests that the French who moved into the Adaes region [indicates the region around the Los Adaes presidio in contrast to the Los Adaes polity which would include Nacogdoches and east Texas] soon after it was abandoned were without doubt familiar with the region and the ranchos themselves. We can assume that the improvements associated with the old ranchos such as cleared fields and buildings were still visible after only a few years. This would seemingly make the abandoned Spanish ranchos prime real estate for the French.

The transition from a Spanish rancho to a French vacherie was possibly an easy undertaking that was perhaps simple as inhabiting an already existing rancho with its old improvements and asking the appropriate authorities for permission to settle. There were however Spanish officials who did not want the French to settle beyond their old territory. Fortunately some officials such as Philipe de Neve believed as long as French settlers obeyed Spanish laws and obtained permission they should be allowed to settle in any Spanish jurisdiction (Béxar 1784). This allowed many settlers to obtain grants within the Adaes and Bayou Pierre regions.

The owners of the land grants in the Adaes region such as Emmanuel Prudhomme and Pierre Sorel dit Marly probably did not live on those grants as they were inhabitants of Natchitoches. The actual grants were occupied by hired hands and slaves left to operate the farm or ranch. This was probably the pattern until Anglo settlers arrived at the close of the eighteenth century.

The ranchos were originally Spanish but truly took on an international flavor as they were resettled by peoples with divergent nativities in the late eighteenth and early nineteenth centuries. These nationalities include French, English, Italian and Irish. This resettlement is detailed within the many volumes of American land claims. This was fortuitous as this left a legacy of historic documents which provide information on the location of the ranchos that had been abandoned by the Spanish many decades earlier.

Each of the ranchos will be discussed individually to best present the data associated with each. Certain ones have much more evidence than others but it is important that those with less data are discussed so as to inform future researchers of the absolute possibility of their presence in the greater Adaes region. 


\section{Llano Hondo}

The only definitive mention of this rancho name was in several depositions given at Los Adaes (Béxar 1754a). Unfortunately no information was given in regard to the location of the rancho. However the geographic location can be deciphered from the few references and from subsequent additional sources.

The key in this search for Rancho Llano Hondo will be the creek named Arroyo Hondo and the adjacent plain simply called the Llano. The two terms seem interchangeable in the manner in which they are used. In essence the plain and the drainage cannot be discussed exclusive of one another as they are obviously geographically interconnected. It must be emphasized that the creek mentioned above is definitely not the same Arroyo Hondo that served as the eastern boundary of the Neutral Ground in the early nineteenth century. That particular creek is located approximately twelve miles further east and is actually within the present city limits of Natchitoches, Louisiana.

The first known descriptions of Llano Hondo occurred in 1754. Within the deposition of Domingo de la Cruz it was stated that he was "farming on the lands of the Llano Hondo" (Béxar 1754a:57). It is obvious from the statement that the rancho name is a geographic term. This is seemingly verified in a statement by Miguel Ramos who was Domingo de la Cruz' brother in law. Ramos states "[Cruz] was not charged anything for the license for settling in the Llano" (Béxar 1754a:54). Marcos Martin the father in law of both Cruz and Ramos states "His Lordship had given license to settle in El Llano Ondo to his, the deponents, son in law, Domingo Cruz ..." (Béxar 1754a:81). These statements all indicate the descriptive nature of the name Llano Hondo which is essentially a reference to a flat plain along a creek named Hondo. The statements above all relate to Hondo or Ondo being a name of a drainage near Los Adaes.

The next mention of the region was by the Marques de Rubi in 1767. This reference seems to indicate a classic case of mistaken identity where the creek has obviously been confused with the Arroyo Hondo boundary near Natchitoches, Louisiana. All who are familiar with Spanish history are fully aware of their fondness for the name Arroyo Hondo from California to Florida. This is primarily due once again to the fact it is a descriptive term.

After crossing the Sabine River on September 11, 1767 the Marques de Rubi traveled through Las Cabezas near present day Zwolle, Louisiana before continuing onto Los Adaes. He arrived later that day at Los Adaes after passing several small farms. Before arriving at Los Adaes the expedition crossed a creek called Arroyo Hondo (Jackson and Foster 1995:129; Chipman and Joseph 1999:184). The fact the expedition was traveling eastward from the Sabine to Los Adaes obviously places the creek to the west of the presidio. This can only refer to the same creek mentioned in the 1754 depositions previously discussed.

The following year Fray Gaspar Jose De Solís made an inspection of the missions of Texas which included a visit to the mission at Los Adaes. On May 8, 1768 the day after crossing the Sabine River he briefly stops and eats at the three plains which is six miles to the west of Los Adaes before continuing his travels east that afternoon. He then states

We came to Arroyo Hondo, a deep creek, where the Reverend Father Amillano came out with many people from the presidio and we reached the mission of Adays about five o'clock in the afternoon [Kress 1931:63-64] 
Fray Solís had just left the three plains [Tres Llanos] area and continued toward Los Adaes when he encountered this creek. This assures us that the creek was also to the west of Los Adaes and is the same creek mentioned by the Marques De Rubi in 1767.

The next reference to the region would be three decades later. In a 1797 inventory of ranches within the jurisdiction of Nacogdoches a French farmer from Natchitoches named Emmanuel Prudhomme was listed as owning a ranch on the "Arroyo Ondo de Los Adaes" (Béxar 1797). This is a direct link to the Marque de Rubi and Fray Solís statements from 1767 and 1768. This is once again a geographical description as was also true for the original name for the rancho. In the 1754 depositions the name of the ranch is usually written as Llano Ondo (Béxar 1754a:32, 68, 81). This is truly too close to deny the similarities in name and location.

In 1813 the valley west of Los Adaes would once again be referred to as "Hondo". This reference is actually located within the American land claims and the particular claim was one of several that were eventually determined to be forgeries and the actual claimants probably fictitious. These claims were not fully transcribed within the official publication of the American State Papers (ASP 1834:210 [these land claims were filed in 1813, the report presented to the House of Representatives in 1816 and the report published in the ASP in 1834]). Each fraudulent claim was only generically labeled as situated along Red River. Fortunately the handwritten documents from this land claim report were located in the Louisiana State Land Office and they were fully transcribed.

Register claim \#903 (Cat. 1205) was supposedly filed by a settler named Julien Florien, however the claimant was probably fictitious. The handwritten claim states the land is situated "on the west side of the reach Hondo, lying on both sides of the Bayou Adays" (LSLO 1813:74 [emphasis mine]). A "reach" in this case is a geographical term for a particular extent of land or water. Bayou Adays [Adaes] is one of the many tributaries of Bayou Dupont. In essence the term "reach Hondo" mimics the name Llano Hondo. This claim while fraudulent does show that once again the original Spanish name Hondo was still applied to the area as late as 1813.

While this claim was eventually negated due to it being fraudulent the information within is still relevant. The supposed perpetrator of the fraud [Richard K. McLaughlin] or co-conspirators were obviously familiar with the geography of the Adaes region. Several known creeks in the area along with Spanish Lake were mentioned in various claims. Also mentioned in one of the fraudulent land claims was "the old vachery of Manuel Prudhomme" lending even more evidence to the credibility of the geographical information within the claims.

Through the years the one consistency in these descriptions is the location of this creek or valley to the immediate west of Los Adaes. This suggests the creek is probably modern Bayou Dupont which flows though the wide flat valley to the west of Los Adaes. The geographic evidence presented supports the region being Rancho Llano Hondo.

In the eighteenth century Jean Pierre Emmanuel Prudhomme from Natchitoches established a ranch at or near the former Rancho Llano Hondo a few years after Los Adaes was abandoned. According to Burton and Smith (2008:153) Emmanuel Prudhomme acquired a square league of land in 1778 at the Adaes Village. This however probably implies he acquired land in the Los Adaes region as there was no "Adaes Village" at that point in time Native or European. The 1778 date is only five years after the abandonment of Los Adaes itself so it is probable the various improvements made by the Spanish were still visible. 
During the American land claims in the nineteenth century Prudhomme filed two claims for the land at the Adaes. Prudhomme filed Register claim \#928 (Cat. 1135) for 640 acres which was situated on Bayou Dupont (ASP 1834:209). This would seem to verify the earlier presumption that Arroyo Ondo and Llano Hondo were in fact Bayou Dupont. Prudhomme would later file Río Hondo claim \#110 in 1823 (ASP 1859:110 [these land claims were filed in 1823, the report presented to the Senate in 1825 and the report published in the ASP in 1859]). This time the claim would be filed for one league square. Plat maps show indisputable evidence of the Río Hondo claim in Township 8 North Range 9 West.

Jean Pierre Emmanuel Prudhomme was a very successful farmer and prominent citizen of Natchitoches, Louisiana who had large land holdings along the Red River which is now Cane River. Oakland Plantation his nineteenth century home is currently the headquarters for the Cane River Heritage National Park along Cane River in Natchitoches Parish, Louisiana. Most of his known history is associated with Natchitoches and the Cane River region. Prudhomme however is also well known in the historical record concerning the Adaes region for the fact that it was he who gave permission to Spanish refugees to settle upon his claim in 1813 (ASP 1859:110). These refugees established the "Village of Adaes" on his property in 1813 (Pleasant and Pleasant 1990). The refugees were fleeing the aftermath of the defeat of the Gutierrez-Magee expedition at the Battle of Medina in 1813. These refugees primarily from Nacogdoches and San Antonio De Béxar were escaping the retaliation by Spanish forces who were arresting and executing many supporters of the expedition. Prudhomme granted permission to the refugees as detailed in Río Hondo claim \#110 (ASP 1859:110).

In his 1823 Río Hondo land claim Prudhomme states his land is "at the Adaise and around the village of Adaise" (ASP 1859:110) but this does not give a definite boundary. As with many of the earlier French and Spanish claims the exact eighteenth century boundaries are unknown. The nineteenth century boundaries of his land claim are well known due to plat maps. In survey documents from 1836 included within the handwritten Río Hondo claim papers Prudhomme states that he would accept sections 3, 4, 5, 8, 9, 10, 15, 16 and 17 in Township 8 North Range 9 West (LSLO 1823a:228). This is the claim as we see it on nineteenth century plat maps. This suggests the original boundaries of his grant were somewhat different and were negotiated for the named sections above. The claim totaled nine square miles and fit well into the Rectangular Survey System employed by the Americans and was relatively equal in size to his original square league. What is likely is that the original boundaries were based on a distance from a central area with improvements and the boundaries of the grant were adjusted by the Americans to fit into the Rectangular Survey System grid. The surveyed claim still obviously encompassed the majority of his original claim in order to include his own improvements on the claim. Samuel Davenport acting as witness for the claimant stated that Prudhomme had "white men, Negroes, horses, \&c., and had houses, pens, \&c., thereon" (ASP 1859:110). So we can assume the boundaries from the plat maps equate closely to the original claim in order to encompass Prudhomme's improvements.

It is probable that Emmanuel Prudhomme claimed an already existing ranch, in particular Rancho Llano Hondo. While there was no location evidence within the Béxar documents the geographical similarities of the name of the rancho and the nearby creek gives us cause to suspect that Prudhommes' claim was the former Rancho Llano Hondo.

Archaeological investigations in 1988 at the Village of Adaes (16NAxx) situated within the bounds of Prudhomme's claim recovered a few sherds of French Faience. One of the types recovered was Provence Blue on White (Waselkov and Walthall 2002; Emery 2004) which has a terminal date of 1765. This suggests that there was some form of occupation in the immediate area of the village during the middle eighteenth century. We can only speculate at this time if these remains are associated with Rancho Llano Hondo. There were also eighteenth century remains found in other areas within the known bounds of Prudhomme's claim which could be indicative of activities at Rancho Llano Hondo. 


\section{Belmudes (Velmudes)}

This rancho was mentioned in two documents from the middle eighteenth century. They do not reveal any information on the location but do provide some minimal information on the owners and activities. The name is spelled differently in the two translations, but a closer inspection of the original documents seems to indicate that "belmudes" was perhaps the actual name used by the Spanish in the 1750s.

The first document is the previously mentioned 1754 depositions by various soldiers in the case against the governor. Don Juan Antonio de Amodin states in his deposition that "Don Pedro del Bario ... had charged Juan Sanches Tovar two or three mules for the title to the Rancho de Velmudes" (Béxar 1754a:69). Juan Sanchez Tovar apparently received the title in 1750. In another reference it was stated that Tovar along with his son-in-laws [one of these was Gil Flores] "had to attend to their cows and mares, [and] the cultivation of chile" (Béxar 1754a:67). The second document from 1755 also consisted of depositions but these were associated with charges against Andres Cherinos for various offenses. The document also decided the ownership of a "skewbald" cow that Chirino was accused of stealing. Within the depositions Miguel de Cordoba mentions "stock brought from Belmudes" (Béxar 1755:20). Unfortunately there is only this single mention of the rancho in the document.

We can possible associate Rancho Belmudes with a Spanish grant mentioned in the American land claims of the nineteenth century. In 1813 the "Widow and Heirs of Martin" filed claim \#499 (Cat. 351) for 1736 arpents of land (ASP 1834:177). This claim was for a Spanish grant signed by Gil Ybarbo on October 18, 1791. The name of the grant was noted to be "Bermudas". The widow and heirs also filed individual claims in 1813 for this tract of land. Luke Martin filed claim \#692 (Cat. 1103), Dominique Martin filed claim \#693 (Cat. 1104) and Theresa Martin [widow] filed claim \#694 (Cat. 1105) (ASP 1834:205). In each of these individual claims the name of the grant is once again stated to be "Bermudas".

A much later land claim from 1840 was filed for this same Spanish grant. A major discrepancy was the Spanish grant in this claim was stated to be 1736 acres instead of arpents. Claim \#127 was filed by the "legal representatives of Joseph Irwin". The land was claimed by "right of settlement of Luke Martin" and the grant was named "Bermudez" (US Serial, 1842:61 [these land claims were filed after 1835, the report presented to the House of Representatives in 1842 and the report was published the same year in the United States Congressional Serial Set]).

The name of the grant within the these land claims is very intriguing and indicates that the Spanish grant of Martin is possibly the former Rancho Belmudes [or Velmudes]. One of the most favorable aspects beyond the name of the grant is the association of Gil Y Barbo, former soldier of Los Adaes and later the commandant of Nacogdoches. It seems apparent that Gil Y Barbo would have been familiar with the ranchos associated with Los Adaes as he was owner of Rancho Lobanillo in East Texas. As such we can assume the use of the grant name "Bermudas" was not a coincidence. This implies direct association between with the former Rancho Belmudes and the Spanish grant "Bermudas".

The deceased Martin noted in the first claim was possibly Pierre Sorel dit Marly of Natchitoches. This can be confirmed to a certain degree by the fact that two of his three documented heirs have the same names as the Sorel family in Natchitoches. Dominique Sorel dit Marly and Luc (Luke) Sorel dit Marly are listed in the 1793 tax rolls of Natchitoches. These two are the sons of Martin while the widow was not mentioned on the tax roll. The case for these being the heirs [sons] and widow of Martin can be seen on a plat map of Township 9 North Range 9 West in which the claimants are more precisely listed as "Widow and Sons of Martin". 
This is obviously the same Pierre Sorel dit Marly mentioned by Burton and Smith (2008:164) as having a ranch near modern Bermuda, Texas. It is quite clear based on all the available evidence such as plat maps and land claims that the Spanish grant of Martin (Marly) was not in east Texas but located just to the northwest of Los Adaes. The relevant historical information attributed to the Marly claim in Texas can now be attributed to the specific geographical locality in northwestern Natchitoches Parish.

The date of the original grant was stated to be October $18^{\text {th }} 1791$ and testimony by Michel DuRoy in 1814 states that the ranch was occupied in approximately 1792 (ASP 1834:177). Burton and Smith (2008:164) state the claim was acquired in 1785. It is probable that the rancho area was not yet resettled before that date as there was no mention of the rancho by Francois Grappe in 1783 in his travel between Los Adaes and the southern region of Bayou Pierre (La Vere 1994). The road from Los Adaes to the Bayou Pierre settlement passed directly adjacent to the improvements (including a house) of the claim of Martin and presumably the settlement would have been noted by the Grappe expedition.

The original grant was for a square league but only a claim for 640 acres was confirmed to the Widow and Heirs of Martin (Marly). Each heir filed for a 640 acre claim but these were never surveyed and do not appear on plat maps. The claim was stated to be for only 640 acres since there was no information on how much land Spanish officials would normally grant (US Serials 1842:61). It is very likely that the entirety of the claim was for the 640 acres as seen on plat maps.

Numerous plat maps of the township show the 640 acre claim of the widow and heirs of Martin. The improvements and a structure probably a house were situated along present day Mayous (Maillieuxs) Bayou in section 38 Township 9 North Range 9 West, about three miles north of Robeline, Louisiana and about one mile to the west of Spanish Lake. The immediate area is currently occupied by a domicile with several houses and structures on the slight rise near where the improvements of Martin are presumed to have been situated. The fact that these noted improvements are in a location that does not seem to have had great disturbances makes this a high priority area to search for mid-eighteenth century archaeological remains.

\section{Tres Llanos}

This seems to be possibly the most well documented of the Los Adaes ranchos with the possible exception of Rancho Lobanillo in east Texas. Tres Llanos is mentioned briefly in early documents (Béxar, 1754a, 1755,1774 ) as well as within various land claims in the early nineteenth century.

The rancho was purchased in 1820 by Charles Pavie and Charles Noyrit who subsequently filed Río Hondo land claim \#240 in 1823 and Register claim \#64 (ASP 1859:136, 508-510 [written as A No. 64]) in 1826. After Pavie and Noyrit purchased the land they also filed a lawsuit against a settler named Louis Latham in 1820 apparently because he was occupying the land without permission. A simplified chronology can be worked out for the rancho based on the information provided by this lawsuit and the land claim.

According to Marian Sanchez Rancho Tres Llanos was granted to his father Jose Sanchez in the mid- $18^{\text {th }}$ century but was abandoned when the Los Adaes population was forced to relocate to San Antonio in 1773. Jose Sanchez left a man named Mansola in charge of the rancho who was still on there in 1774, but soon died on the land. This man left at Tres Llanos is also noted as being named Mendoza in another document concerning illegal activities in the eighteenth century (Béxar 1774:6). This document lists him as the owner of Tres Llanos but apparently he was only left in charge of the rancho due to the evacuation of all Spanish inhabitants of Los Adaes the previous year. Unfortunately beyond this little information there is not much known about the rancho activities in the intervening period from 1774 to 1800. 
In 1800 an Anglo settler named Louis Latham settled on the claim. Latham was obviously one of the many Anglo settlers that began to arrive in the "Adaes" region in the late eighteenth and early nineteenth centuries. According to witness testimony Marian Sanchez had confronted Latham in 1803 and informed him that the land still belonged to him [Sanchez]. It is apparent that Latham did not abandon the property at that point.

Many years later in 1818 Marian Sanchez donated the land to Jose Antonio Sepulveda an inhabitant of the Village of Adaes and fellow Nacogdoches refugee. Sepulveda subsequently sold the land to Pavie and Noyrit in 1820. They immediately initiated the lawsuit in 1820 to remove Louis Latham from the property. The outcome of that suit is unknown but as of 1823 Latham was still on the claim. Latham would later file Río Hondo claim \#2 (ASP 1859:91) in 1823 for the land on the Bayou Three Prairies [Tres Llanos] indicating he still considered the rancho as his property.

Within the testimony in the land claim documents it is stated above that Jose Sanchez was granted Rancho Tres Llanos in the mid-eighteenth century. However in the 1754 depositions it is stated that a soldier named [Christobal] Marques was given license to farm Rancho Tres Llanos (Béxar, 1754a:62). It is unclear at this time if he simply owned the rancho before Jose Sanchez or if perhaps these licenses were given to multiple people to farm the ranchos. This could be the pattern as the testimony of Pedro Procella states, "the inhabitants of the Adizes were settled there [Tres Llanos], raised cattle and made corn" (ASP 1859:509). This indicates that many people potentially occupied Rancho Tres Llanos. Perhaps other ranchos were similar to El Lobanillo and were in fact small "pueblos".

One question that will linger in regard to Rancho Tres Llanos is exactly why Father Solís used the term Rancho de Raso when he was traveling across the Three Plains area just before he reached Los Adaes (Kress 1931:63). Was this another name for Tres Llanos, just a part of the rancho or another rancho in the immediate area? Perhaps this was just a reference to the level plains of the Llano? Father Solís mentioned several known settlements and geographical locations along his journey on the east side of the Sabine River but this one cannot be expanded upon at this time. Regardless of the construct of Rancho de Rasos Father Solís left us a brief description of the orchards at the rancho. He states the orchards contained peaches, figs, berries and of course Castillian roses.

As stated above many of the Los Adaes inhabitants probably lived at the ranch before they were forced to abandon Los Adaes. So there could possibly be a sizable area of mid-18 $8^{\text {th }}$ century remains in the immediate area. Witness testimony in Register claim \#64 (ASP 1859:508-510) states that Louis Latham actually settled on or near the original spot where the house of [Jose] Sanchez was located. The Río Hondo documents and Plat maps of Township 8 North Range 10 West record where Latham's improvements were located which gives us a detailed area to search for remains of Tres Llanos or at least the remains of Jose Sanchez' habitation.

The rancho has a terminus date of 1773 with the exception of the short occupation by Mansola (Mendoza). Several decades would presumably pass before the rancho would be occupied again around 1800. Thus the archaeological remains from the mid-eighteenth century should be easily discernible from the later nineteenth century remains associated with Louis Latham's occupation.

\section{El Baño (Vaño)}

This rancho was owned by the missionaries at Los Adaes and was mentioned in several documents from the mid eighteenth century (Béxar 1754a, 1755; Kress 1931). The general location of the rancho was 
known to be located a short distance to the south of the mission. This was primarily due to the Joseph Urrutia map (Urrutia, 1767) which showed a road leading south from the mission to El Baño. This was confirmed during the visit of Fray Solís in the 1760s as he states El Baño is a half league distant from the mission (Kress 1931:64).

The general area may have been known but not the particular creek where it was situated. A group of nineteenth century land claims south of Los Adaes revealed a more precise location of the rancho and the creek it was located upon. The most definitive evidence involves a creek named Bayou Bain just to the south of the mission area. Apparently Bain is an old French word for bath which indicates a direct connection to El Baño. It is plausible that as the Adaes region was occupied by French inhabitants from Natchitoches the Spanish word Baño was simply replaced by the French word Bain. The succeeding Anglo settlers presumably continued the use of the French name for the bayou.

Fortunately several people filed Río Hondo land claims along Bayou Bain. The claimants include John Sibley who filed Río Hondo claim \#122 for a square league as assignee of Littlepage Robinson (ASP 1859:113). According to the Río Hondo land claim records Littlepage Robinson was the earliest documented inhabitant of Bayou Bain. Robinson reportedly received a grant for a square league from the commandant in Nacogdoches in approximately 1789. It seems he occupied the area until 1800. The land then lay unoccupied until John L. Petit occupied it from 1809 until 1812 when the Spanish and American forces once again ran people out of the Neutral Ground. The claim was once again occupied by Michael Quinn and Henry Quirk in 1814 and subsequently claimed by Sibley. Unfortunately Sibley's claim was not confirmed and probably never surveyed.

John Sibley also filed Río Hondo claim \#123 as assignee of John L. Petit for land along Bayou Bain, whether this was for the same tract of land as Robinsons claim or whether it was a neighboring claim is unknown. It was confirmed and surveyed and is quite evident on various plat maps and includes the site of the Los Adaes presidio and mission.

Sarah Sheridan filed claim \#183 for 640 acres on Bayou Le Bain (ASP, 1859:125). Her land was immediate to the east of John Sibley's claim \#123 and extended down into the open creek valley where Bayou Chacon [Stokers Branch] and Bayou Bain confluence south of Highway 6.

The most important of these claims was that of Michael Quinn simply because of its location. He filed Río Hondo claim \#119 for land at the headwaters of Bayou Bain (ASP 1859:112-113). The original date of occupation is not known but it is obvious that he claimed occupation and cultivation on February 22, 1819. It is quite obviously Quinn was already in the Adaes area around 1813. Quinn's claim is the definitive evidence for the location of Bayou Bain due it being situated on the headwaters of the bayou.

Michael Quinn and Henry Quirk had been tried along with several others in 1810 and 1811 for illegal trade and sedition by the Spanish in Trinidad and then San Antonio de Béxar. Quinn apparently escaped but Quirk and the others were taken to San Antonio and imprisoned for several months. Apparently they were citizens of Nacogdoches at the time. Quinn and Quirk are believed to have joined the Gutierrez-Magee expedition in 1812/1813 and by 1814 they were both refugees living in the Adaes region.

Bayou Bain is not named on modern topographic maps but it is clear from the documentation where it is located. The drainage is relatively short but it is in the right area for "El Baño". The direction in relation to the mission of Los Adaes as mapped by Urrutia as well as the distance described by Fray Solís support the region being Rancho El Baño. The name of the creek is another that seems to have endured after the ranch and Los Adaes were both abandoned. This is another instance in which the Spanish geography was still relevant a half century after Los Adaes was abandoned. 
The valley is wide and flat and probably suited for ranching and agricultural purposes. Plat maps of Township 8 North Range 9 West from the year 1885 reveals Bayou Bain had the largest agricultural fields within the entire township as nearly the entire length of the valley was cultivated. One can presume that this was perhaps a similar case for the eighteenth century if agriculture was part of the Rancho El Baño activities.

This is an area that should be further explored for remains of the rancho. The mapped improvements including the house sites of Michael Quinn and Sarah Sheridan should also be explored for remains of much earlier historic components. Much of the mapped improvements now lie within pine plantations which hopefully have not greatly disturbed potential remains.

\section{La Gloria}

This was an area mentioned only briefly in a document from 1754 (Béxar 1754a). It was just a reference into whether the Los Adaes ranchos could sell enough crops to pay for a church. The whereabouts of the rancho is not mentioned nor was there any usable information within the document.

It was noted that the area was in cultivation in 1754 and as such should be considered another Los Adaes rancho. Juan Sanchez Tovar briefly mentioned the rancho in his testimony regarding the governor of Los Adaes. Tovar states:

When asked whether it was true that for the definite purpose of building the said church the senor governor had proposed to him that the entire community could cultivate the place called La Gloria, which was now being cultivated by the company [Béxar 1754a:101]

Unfortunately at this time there have been no additional eighteenth century references located regarding this place. What we do have is a references within the American land claims that could possibly indicate the location of the rancho.

Seven decades later during the Río Hondo land claims a ranch named La Gloria is mentioned. The "Heirs of Gaspar Fiolle [Fiol] and Theresa Lama Bathey [Lamalathe]" filed Río Hondo claim \#204 in 1823. The claim states:

Situated at a place called "Bayou la Gloria", nine or ten leagues to the westward of the town of Nacogdoches [Natchitoches], containing two leagues square, claimed in virtue of a concession given by Antonio Gily Barvo, commandant of Nacogdoches, dated in 1790, in favor of the ancestor of the claimants for the land claimed [ASP 1859:129]

The above statement refers to the claim being west of Nacogdoches however within the handwritten Río Hondo documents the claim is definitely written as being nine or ten leagues west of Natchitoches (LSLO 1823c:74). The Río Hondo land claims only applied to lands east of the Sabine River and west of the Arroyo Hondo creek [the one near Natchitoches, Louisiana]. So lands anywhere near Nacogdoches would be well outside the Neutral Strip.

Gaspar Fiolle [Fiol] was an Indian trader as early as 1774 . He is mentioned in a document from that year as leading a mule train full of deer hides from the Texas Indians. The Diaz' brothers described under Rancho Vallecillo joined Fiolle and accompanied him to Natchitoches. They obviously traveled through Rancho Vallecillo and several others on their way from Texas to Natchitoches. As described earlier the French from Natchitoches were undoubtedly familiar with the Adaes region and the travel of Gaspar Fiolle provides supporting evidence. 
Figuring out the location of this claim has been rather unfruitful. The claim was placed within the "First Class" which was the class for confirmed claims that were grants and for which title was received by claimants. The title to the claim as with all others was taken by Governor Salcedo in 1812 when he abandoned Nacogdoches, Texas in advance of the Gutierrez-Magee expedition. It is very likely that La Gloria was located in the region near Rancho Tres Llanos to the west of Los Adaes. In Río Hondo claim \#204 Marian Sanchez acts as a witness for the validity of the claim (ASP 1859:129). It is apparent that Sanchez was a neighbor of Fiolles which makes it highly likely that La Gloria was located somewhere to the west of present day Robeline, Louisiana.

There is a map in a Louis Nardini (1961) book which shows a "La Gloria" in the Bayou Pierre settlements. It is situated in the region just north of Bayou Pierre Lake in southern Desoto Parish in a claim attributed to Pierre Baillio. This is obviously completely off base as it is clearly the wrong land owner. That particular claim has a known history of ownership based on the land claim records. Francois Bossier filed claim \#442 (Cat. 45) around 1812 for this particular Bayou Pierre claim. According to the claim record he purchased the land in 1789 from Jacob Hoopock who had only recently purchased it from Pierre "Bouet" Lafitte. Lafitte had been granted the land the previous year. It also is not in the general direction or the correct distance noted in the Gaspar Fiolle claim for La Gloria. Also all the witnesses for Fiolle's claim such as Marian Sanchez are residents of the Adaes region of Natchitoches Parish. Pierre Baillio's land claims are in the general region of Bayou Pierre but are situated to the east along the Red River in section 23 Township 13 North Range 11 West about six miles southeast of Francois Bossier's claim.

\section{Vallecillo}

This place is mentioned in various historical documents from the late eighteenth and early nineteenth century. Most importantly it was mentioned as a rancho in a document from 1774 (Béxar 1774). No geographical description was ever presented but based on the American land claims we can determine a core area that is perhaps the original location of the Rancho Vallecillo. If the popular theory is correct that Vallecillo became corrupted into "Bayou Scie" then we have a very good idea of the location for the rancho.

It must be noted that there was a settlement named Vallecillo in Nuevo Leon, Mexico as well. This small village is located about halfway between Monterey, Mexico and Laredo, Texas. The Béxar documents have many entries which refer to this settlement and not to the rancho in western Louisiana. These documents concern regions such as Monterey and Béxar. The few references for Rancho Vallecillo in Louisiana are readily recognizable within the subject of the documents with references to either Nacogdoches or Natchitoches.

After Los Adaes was abandoned it appears that Rancho Vallecillo was probably sparsely populated but still a quite active place. In 1774 the rancho figured in two official cases that concerned smuggling and illicit trade with the Indians. The two documents mention Rancho Vallecillo several times and as will be shown are actually related as the events in both were happening at approximately the same time. As will be evident, the events of the first document end up intertwining with those of the second. The first document is dated later than the second but the events described within actually began slightly earlier.

The first document dated October 3, 1774 concerns the travels of Joseph Manuel Diaz and his brother Jose Antonio Diaz (Béxar 1774b). It seems the Diaz brothers travels possibly originated at Vallecillo in Mexico and they would eventually end up at Rancho Vallecillo in Louisiana. As a result we must be careful in determining which Vallecillo is referenced in this document. The brothers ultimately became lost on the Brazos River but would eventually make it to a Bidai village in east Texas. An Indian boy from San Antonio named Jose Antonio Cuevas was given to them to work as apprentice to Jose Antonio Diaz who was a shoemaker. At the Indian village they met the Frenchman Gaspar Fiolas (Fiol) from Natchitoches and were employed to help with his mule train of hides. 
As employees of Gaspar Fiolas the two brothers wound up in Natchitoches while the Indian boy remained in Texas at the Indian villages. The brothers were delayed for several days by the commandant of the Natchitoches but finally managed to leave (or escape) and return to Rancho Vallecillo where they expected to find their lost horses. Afterwards they traveled into Texas where they met Gil Ybarbo and the Adaeseños traveling to where they were establishing Bucareli. It was at this point they were arrested and sent to San Antonio de Béxar where they would give their depositions.

The second document from August 1, 1774 contains the depositions of Joaquin Benites, Nepomuzeno Travieso and Juan Antonio Cuevas (Béxar 1774a). Benites and Travieso were members of a large party on a mule train from the Río Grande region to Natchitoches. They were guaranteed safe passage to Natchitoches however at Rancho Tres Llanos they were overtaken by French militiamen and arrested. Only two men avoided being arrested.

Benites testified that he evaded capture by the French militia by hiding in a nearby arroyo. He would eventually make his way to Rancho Vallecillo where he would join another member of the party. This was a man named Mathias Guzman who had been ill and stayed behind to rest at the rancho while the remainder went on to Tres Llanos. Benites and Guzman captured some horses at Vallecillo and made their way back into central Texas.

Nepomuzeno Travieso was captured at Tres Llanos and taken to Natchitoches. He remained in captivity for a while before escaping on foot. He walked to Rancho Tres Llanos where he was able to obtain a mule from the rancho caretaker Mendoza [Mansola]. Once he reached Nacogdoches he was entrusted with an Indian boy from San Antonio named Juan Antonio Cuevas. This is the same Indian boy associated with the Diaz brothers described in the first document. He had been apprenticed to Juan Antonio Diaz the shoemaker. They all would end up turning themselves in to Spanish authorities in Texas.

Travieso stated in his deposition that the residents of Vallecillo were "the Indian [Cuevas], Joseph Manuel [Diaz], his wife who is an Adaeseño, and Marcos Losoya [also an Adaeseño]" (Béxar 1774a:16). It is not clear why Travieso listed these four as living at the rancho. Obviously the Diaz party were only staying for a short time as they would eventually head back to Texas and be captured. Perhaps since Travieso was from the San Antonio region he was unfamiliar with the rancho and considered the Diaz group to be residents of Vallecillo.

The one consistency in both documents is the location of Rancho Vallecillo between the Texas Indians and Natchitoches. The only relevant geographic information within the two documents was offered by Travieso. He stated that Rancho Vallecillo was four leagues beyond the river Sabinas (Béxar 1774:16). This supports the rancho possibly being located along Bayou Scie or in the immediate area.

In the nineteenth century several reports briefly mention the rancho however these are very important due to the late dates. In the first report from 1809 a man named "Querque" was mentioned as "keeping horses at Arroyo de Vallecillo" (Béxar Rolls 1809:290). This is undoubtedly one of the Quirk brothers Edmund or Henry Quirk who were Anglo settlers from Virginia. The Quirk brothers name is usually written as Reymundo Querque and Enrique Querque in Spanish documents. The second report from 1810 list Vallecillo among several places where Americans were settling in the Neutral Ground in western Louisiana (Béxar Rolls 1810:23). The last relevant report was by Ignacio Perez in 1819 regarding the James Long Expedition. Apparently Perez pardoned over thirty former residents of Nacogdoches who were living in horrible conditions at Bayou Pierre, Los Adaes, 
Vallecillo and Tres Llanos (Casteñada 1938:167). The most important aspect of these reports is that even as late as 1809,1810 and up to at least 1819 the area was still known to Spanish officials in Texas as Vallecillo and not Bayou Scie.

The name Bayou Scie does not appear at any point in our search for Rancho Vallecillo before the Río Hondo land claims. It is unfortunate that the name Vallecillo was not mentioned within the American land claims in the nineteenth century which would have narrowed our search to particular tracts of land. Eighteenth century Spanish place names in the immediate region such as Cabezas were mentioned in the Río Hondo claims so it is very surprising that Vallecillo was not. Considering once again the amount of translation that must have taken place during the American land claims the name Vallecillo could have been mentioned and just written as Bayou Scie by various American translators. It is apparent that in the short time period from 1819 to the start of the Río Hondo claims in 1823 there was a transition in nomenclature from Vallecillo to Bayou Scie. We must always be reminded that while the Río Hondo land claims were an American enterprise a majority of the actual claimants were Spanish and French. Most of the claimants of Bayou Scie had been residents of the region for many years ever since the Gutierrez-Magee expedition of 1812/1813. In the 1823 Río Hondo claims every single claim in the immediate area was mentioned as being along Bayou Scie. The absence of a single mention of Vallecillo in the Río Hondo claims suggest the name Bayou Scie may very well come to be an American construct during the early land claim process.

We do have a excellent idea of where the settlement of Bayou Scie was located but at this time we cannot say if that location and Vallecillo are one and the same. The overall settlement was spread out over a large area but there was a definitive core village. The core area had numerous houses in a relatively small area and streets going through the village. It was the end of the eighteenth century or perhaps the beginning of the nineteenth century when the settlement began to attract residents. It is very likely however that the settlement did not attain the dense population seen within the Río Hondo land claims until after the 1813 immigration of refugees fleeing the Spanish after the Battle of Medina. Within the Neutral Ground the populations of Bayou Scie, Village of Adaes, Tres Llanos, and Bayou Pierre all increased dramatically in size due to refugees from Nacogdoches and San Antonio De Béxar. It was Bayou Scie however that had the most densely packed population center.

In the Río Hondo claims there were multiple claimants filing for land in the same exact location, which revealed the rather dense settlement that was probably the village core of the Bayou Scie settlement. Many claims were filed for the same section of land as noted by Deputy Surveyors. In the handwritten Río Hondo claim \#149 of Jean Laurent Burden (LSLO 1823b:254) a Register and Receiver document from 1837 states "now many confirmed claims on the aforesaid quarter of section 28". This is due to there being many people filing for the same 640 acre section earlier in 1823. Approximately twenty five house sites were plotted by surveyors in the small area paralleling Bayou Scie. At least fourteen of these house sites are adjacent to an old road cut which may have been one of the "streets" of the village. The multiple filings seem to once again be a probable result of the fact that before the American land claims people were settling and farming only a few acres and living in close proximity to one another in a village type setting. Once the land claims process began in 1823 village inhabitants filed for 640 acres claims which was the maximum allowed by the Acts of Congress. Many times these claims were for the same tract of land. The claimants filing for the land in section 28 as stated before were living in a village setting. As a result the surveyors plotted their individual houses which revealed a very dense population for the small area.

We do have a map of the nineteenth century Bayou Scie settlement as a result of the search for Rancho Vallecillo. The survey documents among many of the handwritten Río Hondo claims at Bayou Scie often gave 
precise measurements to individual house locations. Several people state within their Río Hondo land claims that they were bound to one side by a street of the village. Shaded relief maps of the region reveal many old road cuts, several of which are possibly these same streets of the village.

Whether the Bayou Scie settlement represents the old Rancho Vallecillo is simply not known but this village area would be a logical starting point for field investigations. Perhaps the refugee population seen in the Río Hondo claims settled on an old rancho much like those farther east near Los Adaes. The area around Tres Llanos was possibly never completely abandoned in the eighteenth century and this could also be true of other ranchos such as Vallecillo.

\section{Petit Ecor}

There is evidence that perhaps some of the Spanish cattle ranching was moved closer to Natchitoches after Spain gained control of Louisiana. It is debatable to whether to include this rancho as a Los Adaes rancho. However as it is mentioned within several documents as both a baquira and a Hacienda we must at least briefly discuss the area.

In 1767 there was a reference in the Béxar Archives to a place named Petit Ecor which is on the outskirts of Natchitoches. This is a name occasionally observed in historic documents relating to Natchitoches, Louisiana and its general location is approximately known. This particular French vacherie named was owned by Luis Menard while Los Adaes was still occupied. It was located on the outskirts of Natchitoches and is only discussed due to the owner Luis Menard being a resident and soldier at Los Adaes.

Luis Menard was also a merchant in Natchitoches and he was obviously a soldier at Los Adaes as he was noted as receiving goods given to the former soldiers of Los Adaes in 1780 while living in Béxar (Béxar 1780a:7; 1780b:2). It is probable that he left the region when the other Adaes residents were marched off to San Antonio in 1773. Documents show him to be a resident of the villa San Fernando (San Antonio) in 1782.

In 1767 depositions there were references by several Spaniards to a "baqueira named the petit ecor" owned by Luis de Menard (Béxar 1767:15). Apparently he was stationing cattle to take to puento cupe (Point Coupee) which was a French settlement north of modern day Baton Rouge, Louisiana. It is not known if this baqueira represented a full rancho type settlement or if this was simply a holding area for livestock waiting to be shipped southward.

In 1769 Luis Menard's ranch is referred to as a "hacienda" (Béxar 1769). This is quite unusual for a Spanish ranch outside the northern areas of Mexico and south Texas to be labeled a hacienda. The ranches on the frontier were simply too small to meet that definition. The two opposing descriptions of the ranch are confusing as a baqueira is essentially a holding pen for livestock while a hacienda is a defacto pueblo associated with a ranch.

In 1823 "The heirs of Francois Rouquier" filed Río Hondo claim \#234 which was stated to be at a place called "La Petit Ecor". It was situated on the west bank of Old River, an old Red River course, immediately west of Natchitoches, Louisiana (ASP 1859:135). The land was purchased from his bother in law Dominique Prudhomme in December 1786 which is almost twenty years after Luis Menard is noted as having a baqueira located there. Francois Rouquire's son Jean Marie Francois Rouquier filed Río Hondo claim \#235 (ASP 1859:135). This claim was issued on October 4, 1786 and was stated to be just below the place called Petit Ecor and located adjacent to Old River. 
The Rouquier claims are situated along the west bank of Old River which was the eastern boundary of the Neutral Ground and as such their claims were Río Hondo claims. Several of the Rouquier claims on the west side of Old River were previously filed during the "Old Board" land claims. The Old Board claim is situated on the uplands overlooking Natchitoches where US Hwy 6 heads westward. The probable location of the Río Hondo claim is a little farther south but still at the base of the uplands. Since the exact locations of their claims are known this could narrow the location of Luis Menards "baqueira named petit ecor" to a general area.

The ability to locate a site such as that of Luis Menard and the ability to distinguish it from an comparable French site would be nearly impossible. We have to presume that at some point the documented Spanish ranchos or baqueiras in the immediate Natchitoches region may never be able to be associated with on the ground remains.

San Joseph

This was a rancho established by Salbador de Esparza sometime before 1754. There is very limited information at present and this consists of a single mention in a document from 1754 (Béxar 1754a:62). At this time no other reference to the rancho has been located. Regardless, we must include it in our discussions since the rancho was mentioned in the historic document in the same respect as the better known ranchos such as $E l$ Baño and Tres Llanos.

While there was no geographic information presented in the 1754 document we can narrow the search area for this rancho. We must once again rely on the Spanish geographical landscape and the apparent unchanging nature of that landscape. The probability that there would be a geographical marker was small but there is a creek named St. Joseph on the Lafon map of 1806 (Lafon 1806) which is located in Sabine Parish near Many, Louisiana. It also seems very unlikely that the creek name would have changed as the region was still primarily Spanish even though ownership of the Neutral Ground was disputed between Spain and the United States. Plat maps from the early nineteenth century reveal the same creek is named St. Hose creek and on modern topographic maps it is named St. Jose. Both are obviously Spanish versions of St. Joseph.

While this can hardly be regarded as evidence of the presence of a former Spanish rancho we can speculate the area is worth field investigations. The El Camino Real crossed this creek as it passed through the Many, Louisiana area. This is also in line with some of the other ranchos in that they are situated along branches of El Camino from Los Adaes toward Nacogdoches, Texas. Also important is the fact that most of the ranchos were named after drainages in the region and some of these names have survived into the present.

In the future it is hoped that mention of St Joseph (Jose/Hose) will be recognized as possibly pertaining to the rancho. Unfortunately the area surrounding St. Jose creek was within the La Nana grant and the Ft. Jesup lands in the early nineteenth century. So limited nineteenth century settlement occurred in the immediate area. This potentially prevented the same type of settlement information in the land claims gained in regard to the other ranchos of Los Adaes.

\section{Summary}

One fact is clear during the discussions of the various ranchos. The rancho names are essentially nothing more than a reference to the primary drainage in the area. Even though we do not have maps of the ranchos from the eighteenth century we can assert with confidence that each ranch was situated on a creek of the same name. I would go as far as to suggest that Rancho Belmudes for example was located on a creek named Bermuda or Belmudes. This is clearly evident on the ranchos El Baño, Tres Llanos and Llano Hondo etc. The only real deviant is Petit Ecore which is actually a French name. 
During the period from the abandonment of Los Adaes to the Río Hondo land claims of the 1820s it seems that the landscape of the eighteenth century changed very little over that half century. This allowed the deciphering of Spanish colonial geography based on data from American land claims.

In the near future hopefully historians will possibly be able to delve deeper into individual histories of each rancho based on the knowledge of their locations and the method in which they were discovered especially those with a possible adequate paper trail such as Rancho Belmudes.

If there were multiple people farming and living at individual ranchos then there could be greater potential for archaeological remains in those areas. For example in the case of Rancho Tres Llanos there was testimony by Pedro Procla (Procello) indicating multiple people were farming the area around Tres Llanos.

An important research topic will also involve searching for definitive evidence of Native Americans at these sites and if there is an identifiable presence that can it be attributed to a particular native group. So far the only mention of natives in relation to the ranchos was a single Native American from San Antonio working at El Baño and an another Indian from San Antonio who was living at Vallecillo. At present there is no documentation indicating that there were additional Native Americans at other ranchos.

The foremost issue is now field verification to determine if there are eighteenth century archaeological remains in the proposed rancho locations. Based on evidence there are several particular areas which appear to have high potential for discovery of those archaeological remains. The research presented within this article is sound but only after relevant archaeological remains are recovered in the proposed locations of the ranchos can we be confident we have discovered the actual whereabouts of the ranchos.

\section{References Cited}

American State Papers (ASP)

1834 Class VIII: Public Lands. Vol. 3. Duff Green, Washington.

1859 Class VIII: Public Lands. Vol. 4. Gales and Seaton, Washington.

Avery, George

2011 The Spanish in Northwest Louisiana, 1721-1773. In Archaeology of Louisiana, edited by Mark A. Rees, pp. 223-234. Louisiana State University Press, Baton Rouge.

Béxar Archives (Béxar)

1754a Translation of citizens of San Fernando vs. Jacinto de Barrios y Jauregui. Dolph Briscoe Center for American History. The University of Texas at Austin. Austin, Texas. Document e_bx_002029.

1754b Translation of proceedings held by Barrios y Jauregui concerning inquiry of subversive activities of Soto Bermudez. It encloses letter from Kerlerec of September 10, 1754 concerning this matter. Dolph Briscoe Center for American History. The University of Texas at Austin. Austin, Texas. Document e_bx_002028.

1755 Translation of proceedings held by Barrios y J'aureui, Juan Pieto, Angel de Martos y Navarrete and Hugo Oconor against Andres Chirinos. Accused of theft, contempt of the authorities and disorderly conduct. Dolph Briscoe Center for American History. The University of Texas at Austin. Austin, Texas. Document e_bx_002034.

1767 Translation of proceedings carried out by Martos y Navarrete by request of Luis de Menard against men charged with abandonment of Menards livestock. Dolph Briscoe Center for American History. The University of Texas at Austin. Austin, Texas. Document e_bx_002184. 
1769 Translation of Jose Gonzales to Governor, reporting detention of Spaniards coming from Natchitoches and of stock supposed to have been stolen from the Spaniards by the Indians. Dolph Briscoe Center for American History. The University of Texas at Austin. Austin, Texas. Document e_bx_002259.

1774a Translation of certified copy of proceedings, Ripperda vs. Joaquin Benitez, Nepomuceno Travieso and Juan Antonio Cuevas, charged with smuggling. Dolph Briscoe Center for American History. The University of Texas at Austin. Austin, Texas. Document e_bx_002433.

1774b Translation of certified copy of proceedings, Ripperda vs. Juan Antonio Diaz and Jose Manuel Diaz, accused of contraband. Dolph Briscoe Center for American History. The University of Texas at Austin. Austin, Texas. Document e_bx_002440.

1784 Translation of Neve to Cabello discussing activities of Le Blanc with the Quitsei Indians and Lafittes's establishment at Nacogdoches. Dolph Briscoe Center for American History. The University of Texas at Austin. Austin, Texas. Document e_bx_006961.

1797 Census drawn by Jose Maria Guadiana. Béxar Archives. Microfilm, Roll 027:77. Cammie G. Henry Research Center, Watson Library. Northwestern State University.

1780a Translation of statement of sums due to soldiers of abandoned presidio of Los Adaes. November 28, 1780. Dolph Brisco Center for American History. The University of Texas, Austin, Austin, Texas.

$1780 \mathrm{~b}$ Translation of report on the distribution of goods to the soldeirs of abandoned presidio Los Adaes. December 11, 1780. Dolph Brisco Center for American History. The University of Texas, Austin, Austin, Texas.

Béxar Archive Rolls (Béxar Rolls)

1809 Letter from Jose Ignacio de Elquezabal to Guadiana, on a report that Querque is keeping horses at Arroyo del Vallecillo. Rolls 35-43 Sept 1806 - Jan 1810, Frame 0808. General Manuscript Series, The Dolph Briscoe Center for American History. The University of Texas.

1810 Guadianas report cocnerning American settlements on the Arroyo de los Adaes, Arroyo del Potrero, La Piedra, El Tapon, Arroyo de la Nana, San Miguel, Vallecillo, Arroyo del Niegreto o del Toro, and Miguel Cro's ranch. Rolls 44-53 Jan 1810 - June 1814, Frame 0573. General Manuscript Series, The Dolph Briscoe Center for American History. The University of Texas.

Burton, H. Sophie and F. Todd Smith

2008 Colonial Natchitoches: A Creole Community on the Louisiana-Texas Frontier. University of North Texas, Denton.

Castaneda, Carlos

1976 Our Catholic Heritage in Texas 1519-1936, Volume VII. Reprinted. Arno Press, New York. Originally published 1938, Von Boeckmann-Jones Company, Austin.

Chipman, Donald E. and Harriet Denise Joseph

1999 Notable Men and Women of Spanish Texas. The University of Texas Press, Austin.

Emery, Jason A.

2004 What Do Tin-Enameled Ceramics Tell Us? Explorations of Social-Economic Status Through the Archaeological Record in Eighteenth Century Louisiana: 1700-1790. Unpublished Masters thesis, Department of Geography and Anthropology, Louisiana State University, Baton Rouge. 
Jackson, Jack, ed. and William C. Foster, annotator

1995 Imaginary Kingdom: Texas as Seen by the Rivera and Rubí Military Expeditions, 1727 and 1767.

Texas State Historical Association, Austin.

Kress, Margaret

1931 Diary of a Visit of Inspection of the Texas Missions Made by Fray Gaspar Jose De Solís in the Year 1767-68. Southwestern Historical Quarterly, Vol. 35, No. 1. pp. 28-76.

Lafon, Barthélémy

1806 Carte générale du territoire d'Orléans comprenant aussi la Floride Occidentale et une portion du territoire du Mississipi /Library of Congress, Geography and Map Division. Washington D.C. http://www.loc.gov/resource/g4010.ct000672/ Accessed 2013

Lavere, David

1998 The Caddo Chiefdoms. Caddo Economics and Politics, 700-1835. University of Nebraska Press, Lincoln and London.

Louisiana Land Office (LSLO)

1813 Claims Entered with Register at Opelousas Under Act of Feb 27, 1813. Document 510.00372.

1823a Río Hondo Claims 80-116. Document 510.00307.

1823b Río Hondo Claims 117-155. Document 510.0031.

1823c Río Hondo Claims 193-230. Document 510.00309.

Nardini, Louis R.

1961 No Man's Land: A History of El Camino Real. Pelican Publishing Company, Gretna.

National Park Service (NPS)

2011 El Camino Real de los Tejas National Historic Trail: Comprehensive Management Plan/ Environmental Assessment. National Trails Intermountain Region. National Park Service.

Pleasant, Darryl

2013 The Eighteenth and Nineteenth Century Location of the Adaes Indians. Caddo Archaeology Journal, Vol 23 pp. 115-140.

Pleasant, Randall and Darryl Pleasant

1990 The Adaes Village: Archaeological Research on an Nineteenth Century Spanish-American Site. Paper Presented at the 1990 Caddo Conference, Natchitoches, Louisiana.

United States Congressional Serial Set (US Serial)

1842 H.R. Doc. No. 33, 27 ${ }^{\text {th }}$ Cong., $2^{\text {nd }}$ Session.

Urrutia, Joseph

1767 Plano del Presidio de Nuestra Senora del Pilar de los Adaes Capital de los Tejas. British Museum.

1769 Mapa, que comprende la Frontera, de los Dominios del Rey, en la America Septentrional. Library of Congress. Map Collections. http://www.loc.gov (accessed August 31, 2013) 
Waselkov, Gregory A. and John A. Walthall

2002 Faience Styles in French Colonial North America: A Revised Classification. Historical Archaeology. Vol 36(1) pp. 62-78.

Williams, Jeffrey M.

2007 GIS Aided Archaeological Research of El Camino Real de los Tejas with Focus on the Landscape and River Crossings along El Camino Carretera. Unpublished Masters thesis, Stephen F. Austin State University, Nacogdoches, Texas. 